\title{
Extracellular and membrane-bound $\beta$ lactamase of Staphylococcus aureus: their importance for the expression of penicillin resistance
}

\author{
W. BRUNS and H. KEPPELER
}

\section{Pharmakologisches Institut der Universität zu Köln, Gleuelerstrasse 24, D-5000 Cologne 41, Federal Republic of Germany}

Summary. The synthesis and excretion of $\beta$ lactamase by several strains of Staphylococcus aureus from different clinical sources and the ability of both the extracellular and membrane-bound enzyme to mediate penicillin resistance was studied. When $\beta$-lactamase production was maximally induced with penicillin $\mathrm{G}$ or ampicillin, about $50 \%$ of the $\beta$ lactamase was excreted from the cells, the amount of extracellular enzyme correlating well with the degree of resistance established by an in-vitro test model. From penicillin-binding experiments it became apparent, however, that the membrane-bound $\beta$ lactamase can also constitute a barrier, strong enough on its own to prevent penicillins from reaching their target. This could be of clinical relevance if, under certain conditions in vivo, the extracellular $\beta$ lactamase is insufficient for full protection of the staphylococcal cells.

\section{Introduction}

$\beta$ Lactamases contribute significantly to the resistance of Staphylococcus aureus to penicillins. Because some of the enzyme produced is excreted into the surrounding medium it can act on hydrolysable penicillins before these have penetrated the cells (Richmond and Curtis, 1974). Although the proportion of extracellular $\beta$ lactamase produced by different staphylococcal strains varies greatly from $<10 \%$ to $>80 \%$ (Richmond, 1975; Dyke, 1979), the general importance of the exoenzyme in the expression of penicillin resistance is not questioned. However, data relating the quantity of extracellular $\beta$ lactamase produced to the level of resistance that results are not available. Furthermore, the extent to which the intracellular $\beta$ lactamase contributes to resistance is not clear. Nielsen and Lampen (1982) have shown that intracellular $\beta$ lactamase is firmly fixed to membrane lipids, and is therefore close to the penicillin target sites.

This paper describes a study of the synthesis of $\beta$ lactamase by staphylococcal strains from different clinical sources; its extra- and intracellular distribution; the relationship between the amount of exoenzyme produced and degree of resistance (examined by means of an in-vitro test model) and the significance of membrane-bound $\beta$ lactamase

Received 12 May 1986; accepted 16 Jul. 1986. for expression of resistance (investigated by means of penicillin-binding experiments).

\section{Materials and methods}

\section{Organisms}

Penicillin-resistant strains of Staphylococcus aureus from different sources were used. Strains 6641, 4503, $5814 \mathrm{~S}, 5814 \mathrm{R}$ and $\mathrm{S} 108$ were resistant to penicillin $\mathrm{G}$ and ampicillin, and one of them (5814R) was resistant to methicillin also. Strains $5814 \mathrm{R}$ and $5814 \mathrm{~S}$ were originally isolated from a strain of mixed population (Rozgonyi, 1976). The strains were kindly provided by: G. Pulverer, Universität zu Köln, Cologne, Federal Republic of Germany (FRG) (strains 6641 and 4503, the latter originally isolated by P. Oeding, University of Bergen, Bergen, Norway); F. Rozgonyi, University Medical School, Debrecen, Hungary (strains 5814S and 5814R); and $O$. Zwisler, Behringwerke AG, Marburg, FRG (strain S108). A penicillin-susceptible strain, $S$. aureus $\mathrm{H}$, was also used. It was kindly provided by K.-H. Schleifer, Technische Universität München, Munich, FRG.

\section{Antibiotics}

${ }^{14} \mathrm{C}$-penicillin $\mathrm{G}(54 \mathrm{mCi} / \mathrm{mmol})$ was purchased from Amersham Buchler, Braunschweig, FRG. Methicillin and clavulanic acid potassium salt were gifts from $\mathrm{Dr}$ Hulla, Beecham-Wülfing GmbH and Co. KG, Neuss, FRG. Penicillin $G$ was obtained from Hoechst AG, Frankfurt/Main, FRG, ampicillin was from Bayer AG, 
Leverkusen, FRG. Nitrocefin was kindly provided by Glaxo Pharmazeutika GmbH, Bad Oldesloe, FRG.

\section{Susceptibility tests}

The MICs of the penicillins were determined by twofold serial dilution in Mueller-Hinton Broth (Oxoid) as described by Ericsson and Sherris (1971) with an inoculum of $(0 \cdot 5-1) \times 10^{6} \mathrm{cfu} / \mathrm{ml}$. After incubation at $37^{\circ} \mathrm{C}$ for $20 \mathrm{~h}$ the MIC was recorded as the lowest concentration that inhibited growth.

\section{$\beta$-Lactamase synthesis}

These experiments were performed in Brain Heart Infusion Broth (Oxoid). Overnight cultures of the staphylococci were diluted 1 in 40 with fresh medium and grown to early logarithmic phase while being shaken in a water bath at $37^{\circ} \mathrm{C}$. To induce $\beta$-lactamase synthesis, penicillin $\mathrm{G}$ or ampicillin at concentrations of $0.5,5,50$ or $500 \mathrm{mg} / \mathrm{L}$ or methicillin $0.5 \mathrm{mg} / \mathrm{L}$ was added and cultivation continued. Simultaneously, cultures were grown without added penicillin to measure uninduced $\beta$ lactamase production. Growth was measured by reading optical density in a spectrophotometer (PMQ II, Zeiss) at $600 \mathrm{~nm}$. The $O D$ values were converted to $\mathrm{mg}$ of bacterial dry weight $/ \mathrm{ml}$ by reference to standard curves. Samples were taken at intervals from each culture and 8hydroxyquinoline to a final concentration of $0.83 \mu \mathrm{mol} /$ $\mathrm{ml}$ was added to stop growth and induction. The $\beta$ lactamase activity of whole cultures was measured with nitrocefin as substrate (O'Callaghan et al., 1972), one unit of $\beta$ lactamase (NCF unit) being defined as the amount of enzyme hydrolysing $1 \mu \mathrm{mol}$ of nitrocefin $/ \mathrm{min}$ at $37^{\circ} \mathrm{C}$. Exoenzyme activity was measured as the activity present in culture supernates after centrifugation. The amount of intracellular $\beta$-lactamase activity was calculated as the difference between the amount of activity in whole cultures and of exoenzyme.

\section{In-vitro model for simulation of "extracellular" penicillin resistance}

To examine the effectiveness of extracellular $\beta$ lactamase in mediating penicillin resistance on its own, cells of the penicillin-susceptible $S$. aureus strain $\mathrm{H}$ were supplemented with $\beta$ lactamase isolated from strain $\mathrm{S} 108$ and purified as described by Richmond (1975). Logarithmic growth rates of both strains were similar. To cultures of strain $\mathrm{H}$, grown to the early logarithmic phase at $37^{\circ} \mathrm{C}$ $\left(\mathrm{OD}_{600 \mathrm{~nm}} 0 \cdot 13\right)$, the $\beta$ lactamase was added at intervals of $15 \mathrm{~min}$ for up to $1 \mathrm{~h}$ in concentrations corresponding to the amount of extracellular $\beta$ lactamase formed in cultures of strain S108 uninduced or induced with ampicillin. Simultaneously with the first addition of $\beta$ lactamase, ampicillin in various concentrations was added to strain $\mathbf{H}$ and growth was monitored spectrophotometrically. To ensure that the $\beta$ lactamase added to strain $\mathbf{H}$ remained extracellularly and did not penetrate into the cells, cultures of strain $\mathrm{H}$, treated with $\beta$ lactamase as described above, were centrifuged and the enzyme activity was determined in both the pellet and the supernate. In these control experiments not more than $2 \%$ of the $\beta$ lactamase added was found to be absorbed by the cells of strain $\mathrm{H}$.

\section{Binding of ${ }^{14} C$-penicillin $G$ to staphylococcal membranes}

Washed cells harvested after growth for $2 \mathrm{~h}$ in Brain Heart Infusion Broth (Oxoid) at $37^{\circ} \mathrm{C}$ were disintegrated with lysostaphin and cytoplasmic membranes prepared as described previously (Bruns and Keppeler, 1980). Membrane samples, containing protein $1 \mathrm{mg} / \mathrm{ml}$ in $0.05 \mathrm{M}$ Tris buffer at $p \mathrm{H} \mathrm{7.5}$ containing $0.02 \mathrm{M} \mathrm{MgSO}_{4}$, were incubated with various concentrations of ${ }^{14} \mathrm{C}$ penicillin $\mathrm{G}$ at $37^{\circ} \mathrm{C}$ for $15 \mathrm{~min}$. The reaction was stopped by adding 1000 -fold excess of non-radioactive penicillin G. The membranes were centrifuged at $40000 \mathrm{~g}$ for 30 min at $4^{\circ} \mathrm{C}$, washed with buffer and dissolved in sodium dodecyl sulphate $0.5 \% \mathrm{w} / \mathrm{v}$. The radioactivity was measured in a liquid scintillation counter (Intertechnique, Mainz, FRG).

Membrane-bound $\beta$ lactamase was measured as described above. To induce $\beta$-lactamase production the cells were cultured in the presence of penicillin $G$ at a concentration of $5 \mathrm{mg} / \mathrm{L}$. Membrane-bound enzyme was inhibited by first treating the cells with clavulanic acid at a concentration of $0.1 \mathrm{mg} / \mathrm{L}$ for $15 \mathrm{~min}$ before adding ${ }^{14} \mathrm{C}$-penicillin $\mathrm{G}$.

\section{Results}

\section{$\beta$-Lactamase synthesis}

When the synthesis of $\beta$ lactamase by five penicillin-resistant strains of $S$. aureus, before and after induction with penicillin $\mathrm{G}$, ampicillin or methicillin, was studied, little enzyme was produced by uninduced cultures and specific activity decreased slightly during the 3 -h period of observation. In the presence of any of the penicillins the synthesis of $\beta$ lactamase increased but the amounts produced differed significantly depending on the strain and the antibiotic used. For example, when any of the penicillins was added to cultures of strain S108 activity rose 5-10-fold within $15 \mathrm{~min}$ (fig. 1). With ampicillin and penicillin $G$, maximum values were obtained after $30 \mathrm{~min}$. At this time, $\beta$ lactamase production induced by ampicillin was about twice that with penicillin $G$ and more than 15 times the basal value. Subsequently $\beta$-lactamase synthesis decreased and approached the level of $\beta$ lactamase production in uninduced cultures. Maximal induction by these two penicillins was obtained with concentrations of $5 \mathrm{mg} / \mathrm{L}$. With higher concen- 


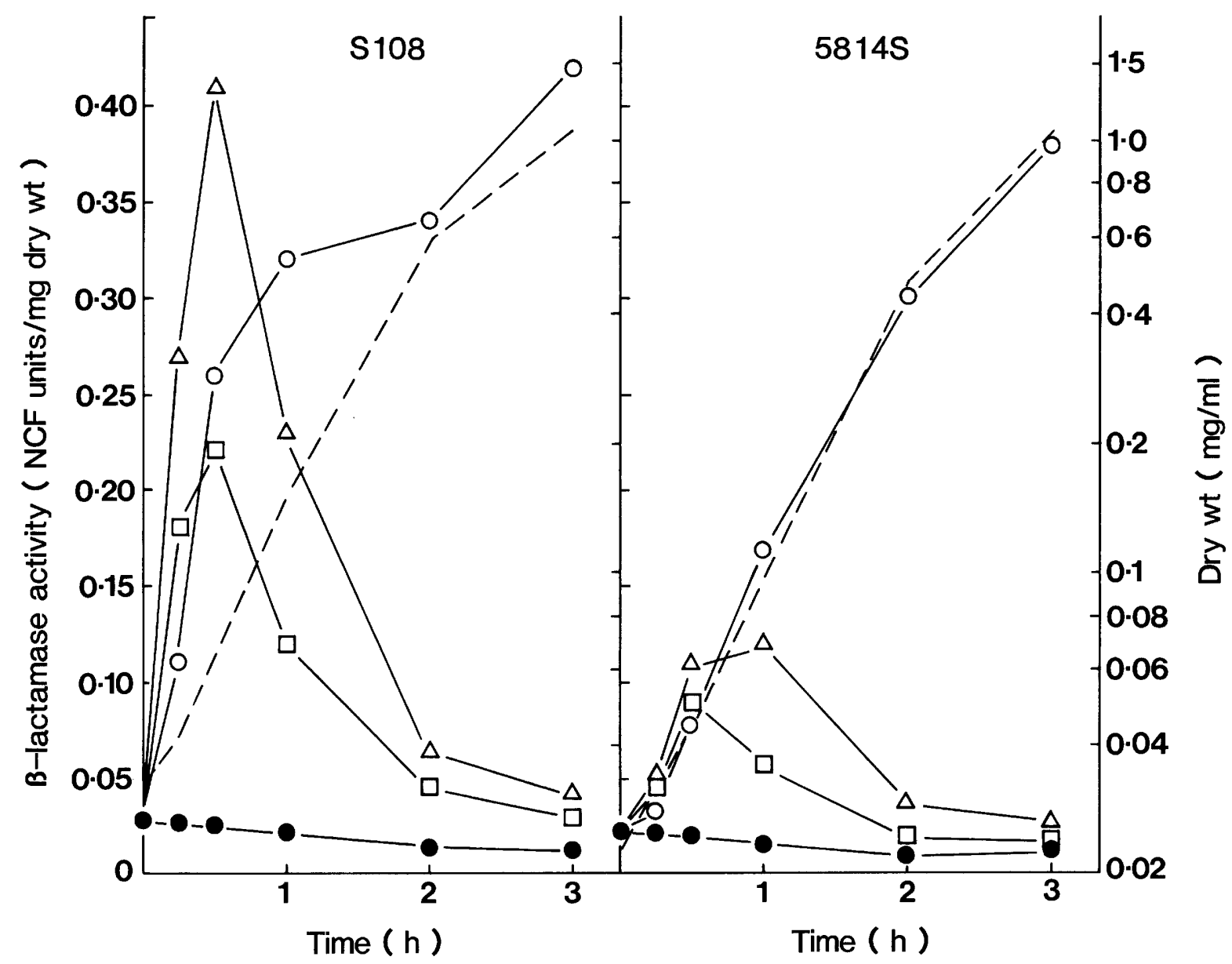

Fig. 1. Growth (--) and $\beta$-lactamase synthesis of $S$. aureus strains $S 108$ and $5814 \mathrm{~S}$, uninduced $(O)$ and after induction with penicillin $\mathrm{G} 5 \mathrm{mg} / \mathrm{L}(\square)$, ampicillin $5 \mathrm{mg} / \mathrm{L}(\triangle)$, and methicillin $0.5 \mathrm{mg} / \mathrm{L}(\mathrm{O})$. Examples for high and low inducibility, in particular with penicillin $\mathrm{G}$ and ampicillin.

trations the effect was not enhanced. In contrast, $\beta$ lactamase synthesis by strain $5814 \mathrm{~S}$ was induced by ampicillin or penicillin $\mathrm{G}$ to a small extent only (fig. 1). In the presence of ampicillin which was again more effective than penicillin $\mathrm{G}$, the level of $\beta$-lactamase production was about $30 \%$ of that of strain $\mathrm{S} 108$ and reached its maximum only after 60 min. $\beta$-Lactamase production by the three other strains was comparable to that of either strain $\mathrm{S} 108$ or strain 5814S (table I). Production by strains 6641 and 4503 was induced to a similar extent as in strain S108. Induction of production, in strain 5814R, the only strain resistant to methicillin also, was slow and $\beta$-lactamase production was smaller even than that of the isogenic strain $5814 \mathrm{~S}$.

When methicillin at a concentration of $0.5 \mathrm{mg} / \mathrm{L}$ was used to induce each strain, there was, as was to be expected, a continuous increase of $\beta$-lactamase synthesis. The results with strains S108 and 5814S are shown in fig. 1. Maximum enzyme induction was not seen during the period of observation. After $3 \mathrm{~h}$ the level of $\beta$-lactamase activity was higher in every case than the maximum value obtained by induction with ampicillin or penicillin $\mathrm{G}$, being 20-45 times that of uninduced cultures.

The maximum levels of $\beta$ lactamase induced by penicillin $\mathrm{G}$ or ampicillin were related to the strains' MICs (table I), the $\beta$-lactamase production of the three most resistant strains being about thrice that of the two least resistant, i.e., of the same order as the differences in the strains' MICs.

\section{Extracellular $\beta$ lactamase}

The ratio of extracellular to intracellular $\beta$ lactamase was determined at the time of maximum 
Table I. Susceptibility to penicillin $G$ or ampicillin and $\beta$-lactamase production by $S$. aureus

\begin{tabular}{|c|c|c|c|c|c|}
\hline \multirow{3}{*}{$\begin{array}{l}\text { Strain } \\
\text { no. }\end{array}$} & \multirow{2}{*}{\multicolumn{2}{|c|}{$\mathrm{MIC}(\mathrm{mg} / \mathrm{L})$}} & \multicolumn{3}{|c|}{$\begin{array}{c}\beta \text {-Lactamase activity of whole cul- } \\
\text { tures(NCF units) }\end{array}$} \\
\hline & & & \multicolumn{2}{|c|}{$\begin{array}{l}\text { maximally } \\
\text { induced }^{*} \text { by }\end{array}$} & \multirow[t]{2}{*}{ Uninduced } \\
\hline & $P C-G$ & AMP & PC-G & AMP & \\
\hline S108 & 1000 & 2000 & $0 \cdot 22$ & 0.41 & 0.024 \\
\hline 6641 & 1000 & 2000 & 0.26 & 0.33 & 0.025 \\
\hline 4503 & 1000 & 1000 & $0 \cdot 26$ & 0.34 & 0.026 \\
\hline $5814 \mathrm{~S}$ & 250 & 500 & 0.091 & $0.12 \dagger$ & 0.020 \\
\hline $5814 \mathrm{R}$ & 250 & 500 & $0.056 \dagger$ & $0.093 \dagger$ & $0 \cdot 017$ \\
\hline
\end{tabular}

* Maximal amounts of enzyme were obtained $30 \mathrm{~min}$ or $60 \mathrm{~min}$ ( $\dagger$ ) after induction with penicillin $\mathrm{G}(\mathrm{PC}-\mathrm{G}) 5 \mathrm{mg} / \mathrm{L}$ or ampicillin (AMP) $5 \mathrm{mg} / \mathrm{L}$. For comparison the $30-\mathrm{min}$ values of uninduced enzyme are listed.

enzyme synthesis after induction with penicillin $G$ or ampicillin (table II). Minor differences only were found between the five strains. Generally about $50 \%$ of the enzyme was excreted, the highest value $(57 \%)$ being that of strain $5814 \mathrm{~S}$ induced with ampicillin, the lowest $(42 \%)$ that of strain $\mathrm{S} 108$ induced with penicillin $\mathrm{G}$. Less than $40 \%$ of the $\beta$ lactamase produced by uninduced cultures was excreted after $30 \mathrm{~min}$. With methicillin as inducer the amount of extracellular $\beta$ lactamase produced by the five strains differed more widely (table III) values after $3 \mathrm{~h}$ varying from $20 \%$ to $50 \%$. Strain 6641 , which produced the greatest amount of total $\beta$ lactamase, excreted least $(22 \%)$. On the other hand, the poorly inducible strains 5814 S and $5814 \mathrm{R}$ excreted about $50 \%$ of their $\beta$ lactamase.

The significance of extracellular $\beta$ lactamase in mediating resistance to ampicillin was studied by

Table II. Extracellular $\beta$ lactamase of $S$. aureus

\begin{tabular}{l|lcc}
\hline & \multicolumn{3}{|l}{ Production* of extracellular $\beta$ lactamase } \\
\cline { 2 - 3 } & \multicolumn{2}{c}{ after induction with } & uninduced \\
\cline { 2 - 3 } Strain & PC-G & AMP & \\
no. & 42 & 52 & 38 \\
\hline S108 & 50 & 51 & 38 \\
6641 & 52 & 51 & 36 \\
4503 & 49 & 57 & 39 \\
5814 S & 50 & 51 & 36 \\
\hline
\end{tabular}

* Percentage of total enzyme. PC-G=penicillin G; $\mathrm{AMP}=$ ampicillin .
Table III. $\beta$-Lactamase production by five strains of $S$. aureus induced with methicillin $0.5 \mathrm{mg} / \mathrm{L}$ for $3 \mathrm{~h}$

\begin{tabular}{l|cc}
\hline & \multicolumn{2}{|c}{ Amount of enzyme } \\
\cline { 2 - 3 } $\begin{array}{l}\text { Strain } \\
\text { no. }\end{array}$ & $\begin{array}{c}\text { Total } \\
\text { (NCF units/mg } \\
\text { dry wt) }\end{array}$ & $\begin{array}{c}\text { Extracellular } \\
\text { (percentage of } \\
\text { total enzyme) }\end{array}$ \\
\hline S108 & 0.42 & 33 \\
6641 & 0.85 & 22 \\
4503 & 0.53 & 38 \\
$5814 S$ & 0.38 & 51 \\
$5814 \mathrm{R}$ & 0.17 & 49 \\
\hline
\end{tabular}

adding $\beta$ lactamase from strain S108 to cells of the ampicillin-susceptible strain $\mathrm{H}$ in the logarithmic phase in concentrations mimicking exoenzyme formation by strain S108 after induction with ampicillin. The ampicillin resistance of strain $\mathrm{H}$ in these circumstances was almost equal to that of strain S108 (fig. 2), ampicillin at a concentration of $5000 \mathrm{mg} / \mathrm{L}$ being required to inhibit the growth of either strain completely. If amounts of exoenzyme equal to those in uninduced cultures of strain S108 were added to strain $\mathrm{H}$, ampicillin concentrations of only about $25 \mathrm{mg} / \mathrm{L}$ were needed to inhibit growth of the latter strain.

\section{Membrane-bound $\beta$ lactamase}

As stated above, about $50 \%$ of the $\beta$ lactamase produced remained within the cells. This fraction, which is of special interest, is firmly fixed to the membrane lipids by a thioether linkage (Nielsen and Lampen, 1982) close to penicillin target sites. To evaluate its importance in the expression of resistance its amount was measured and its influence on the binding of ${ }^{14} \mathrm{C}$-penicillin $\mathrm{G}$ to its targets was studied.

Cells of strains S108, 4503, and 5814S grown for $2 \mathrm{~h}$ in the presence or absence of penicillin $\mathrm{G}$ at a concentration of $5 \mathrm{mg} / \mathrm{L}$ to induce $\beta$-lactamase production were disintegrated and the membranes isolated. $\beta$ Lactamase was found in all membrane fractions (table IV). Membrane preparations from uninduced cells contained 0.02-0.04 NCF units/mg of membrane protein, whereas those from induced cells contained $0 \cdot 2-0.7 \mathrm{NCF}$ units/mg of proteinat least a.tenfold increase. When the binding of ${ }^{14} \mathrm{C}$-penicillin $\mathrm{G}$ to membranes of uninduced and induced cells of strains S108, 4503 and 5814 S was studied, only small amounts of penicillin were bound non-specifically to membranes from uninduced cultures with little $\beta$-lactamase activity. 


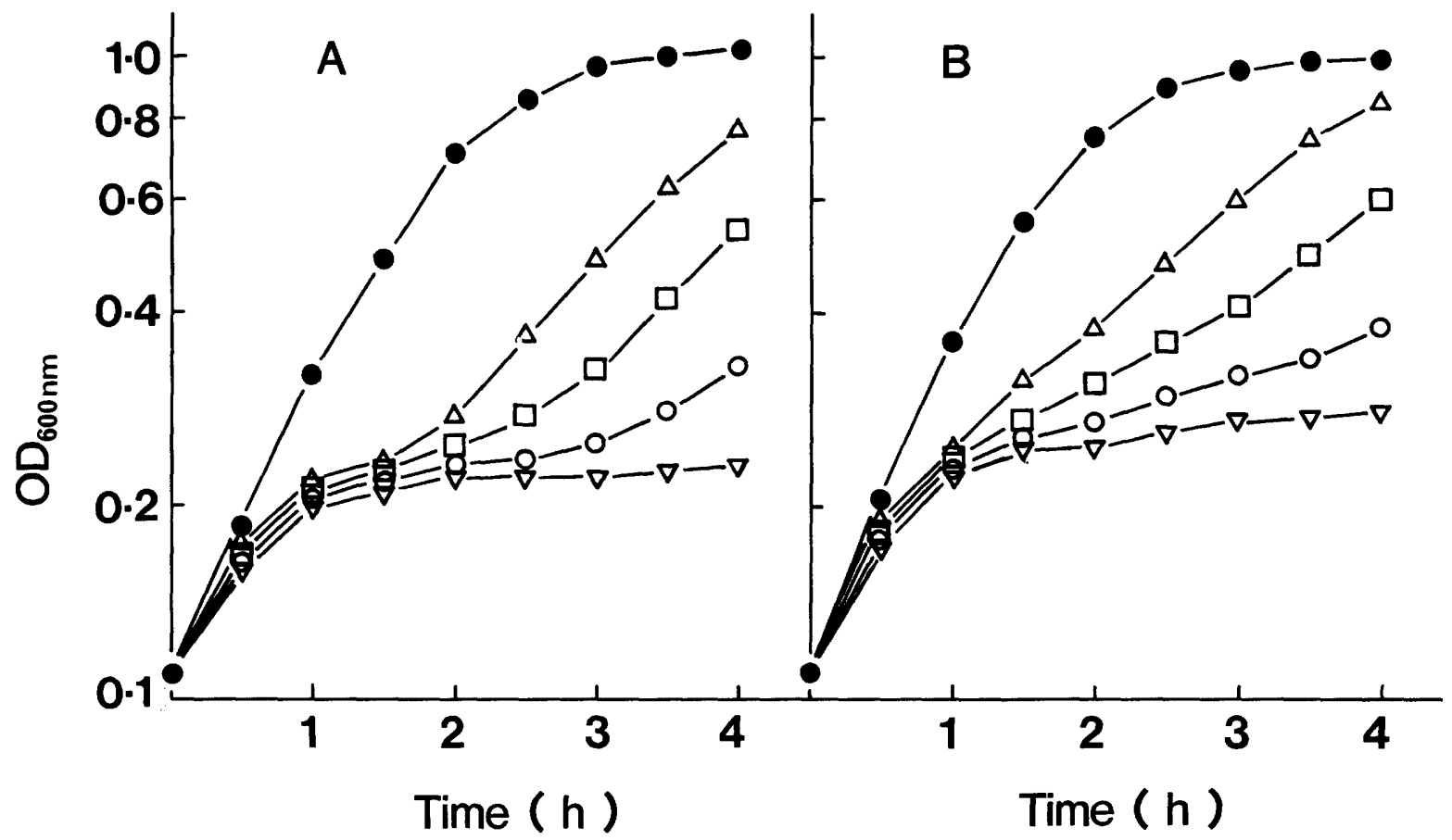

Fig. 2. Susceptibility of $S$. aureus $H$ to ampicillin after addition of extracellular $\beta$ lactamase from strain $S 108$ (A). For comparison the response of the donor strain (S108) to ampicillin is shown (B). At times $0,15,30,45$, and 60 min $0 \cdot 5,5,6,3$, and 2 nitrocefin units/L of $\beta$ lactamase were applied to strain $H$ simulating formation of extracellular $\beta$ lactamase in S108 after induction with ampicillin. To both strains ampicillin in concentrations of $500 \mathrm{mg} / \mathrm{L}(\triangle), 1000 \mathrm{mg} / \mathrm{L}(\square), 2000 \mathrm{mg} / \mathrm{L}(\bigcirc)$, and $5000 \mathrm{mg} / \mathrm{L}(\nabla)$ was added at time 0 . control.

Results with strain S108 are shown in fig. 3. However, when the membranes were first treated for $15 \mathrm{~min}$ with clavulanic acid at a concentration of $0.1 \mathrm{mg} / \mathrm{L}$ not only was the binding of ${ }^{14} \mathrm{C}$ penicillin $\mathrm{G}$ markedly increased, but the binding was highly specific. Half saturation was obtained with a concentration of penicillin $\mathrm{G}$ of $0.1 \mathrm{nmol} /$ $\mathrm{ml}$.

\section{Discussion}

It is generally accepted that $\beta$ lactamases are predominantly responsible for the resistance to

Table IV. Membrane-bound $\beta$ lactamase of S. aureus

\begin{tabular}{l|cc}
\hline & \multicolumn{2}{|c}{ NCF units/mg membrane protein } \\
\cline { 2 - 2 } Strain & uninduced & induced* \\
no. & 0.041 & 0.665 \\
\hline S108 & 0.035 & 0.400 \\
4503 & 0.024 & 0.184 \\
$5814 S$ & & \\
\hline
\end{tabular}

*With penicillin $G 5 \mathrm{mg} / \mathrm{L}$ for $2 \mathrm{~h}$. penicillin of strains of $S$. aureus. However, a strong relationship between the amount of enzyme produced and the resulting level of resistance has not been confirmed (Saz, 1970), and Gill et al. (1981) even found that some strains of $S$. aureus were susceptible to penicillin $G$ at concentrations of $0.05 \mathrm{mg} / \mathrm{L}$ or less despite producing $\beta$ lactamase. By contrast, in the present study, there was a distinct correlation between induced $\beta$-lactamase production by staphylococcal strains from various sources and their resistance to penicillin $G$ or ampicillin: the greater the amount of $\beta$ lactamase produced after induction with either antibiotic the higher was the level of resistance (table I).

Staphylococcal $\beta$ lactamase is partially excreted into the surrounding medium where it inactivates penicillins before they can reach their target sites at the cytoplasmic membrane. It has been assumed that $>80 \%$ of the $\beta$ lactamase is normally released from the cells (Richmond and Curtis, 1974; Richmond, 1975; Ogawara, 1981). However, different strains excrete different amounts depending, at least in part, on growth conditions (Coles and Gross, 1967; Kim and Chipley, 1974; Dyke, 1979). One particular strain of $S$. aureus excreted $<1 \%$ but this might be an exception (Batchelor et al., 


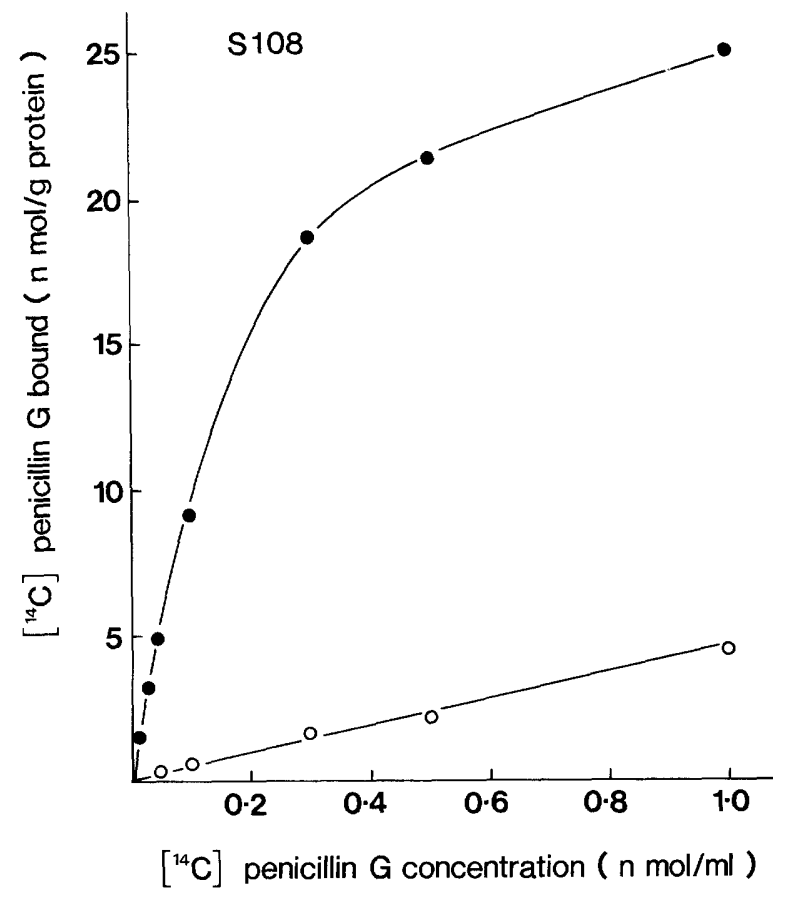

Fig. 3. Binding of ${ }^{14} \mathrm{C}$-penicillin $\mathrm{G}$ to membranes of the penicillin-resistant strain $S$. aureus $\mathrm{S} 108$ incubated for $15 \mathrm{~min}$. This was done with $(O)$ or without $(O)$ previous treatment for $15 \mathrm{~min}$ with clavulanic acid at a concentration of $0.1 \mathrm{mg} / \mathrm{L}$.

1963). The strains described in the present study showed intermediate behaviour: at maximum induction with penicillin $\mathrm{G}$ or ampicillin c. $50 \%$ of the $\beta$ lactamase measured was extracellular, whereas when uninduced only $35-40 \%$ was excreted. The response when methicillin was used for prolonged induction was heterogeneous; the proportion of $\beta$ lactamase excreted varied between $20 \%$ and $50 \%$ and was not related to the total amount synthesised. Strain 6641 produced the greatest total amount of $\beta$ lactamase but excreted the least.

The extent to which extracellular $\beta$ lactamase mediates resistance to ampicillin was tested in an in-vitro model which, by incorporating $\beta$ lactamase from the donor strain $S 108$, mimicked $\beta$-lactamase synthesis by cultures of the penicillin-susceptible strain $\mathrm{H}$. Under these conditions, adding the levels of extracellular $\beta$ lactamase produced by ampicillininduced cultures of strain S108 to cultures of strain $\mathrm{H}$ raised the ampicillin resistance of the latter to the natural resistance of the donor strain, i.e., $>$ $2000 \mathrm{mg} / \mathrm{L}$ (fig. 2). When an amount of extracellular $\beta$ lactamase equal to that in uninduced cultures of strain S108 (about $5 \%$ of that in induced cultures) was added, a correspondingly lower level of resistance of about $25 \mathrm{mg} / \mathrm{L}$ resulted.
The role of intracellular $\beta$ lactamase in the resistance of staphylococci to penicillin is not so clear. In this genus and in other gram-positive bacteria, intracellular $\beta$ lactamase is firmly bound to the cytoplasmic membranes (Nielsen and Lampen, 1982). In vitro, the importance of extracellular $\beta$ lactamase in determining resistance predominates but this may not be true in vivo. $\beta$ Lactamases in the environment of the bacterial cells can be diluted by diffusion (Haller, 1984) or their effectiveness may be reduced by other tissue factors, e.g., low $p \mathrm{H}$ values in inflamed tissues, the action of proteases and oxygen radicals formed during phagocytosis, or inactivation by antibodies. Membrane-bound $\beta$ lactamase may therefore provide a second line of defence which could be highly effective because it is located close to the target sites of penicillin (Bush and Sykes, 1984).

This view is supported by the studies described here of the binding of ${ }^{14} \mathrm{C}$-penicillin $\mathrm{G}$ to staphylococcal cell membranes. Binding to membranes from penicillin-resistant strains was non-specific only (fig. 3), but when membrane-bound $\beta$ lactamase was first inhibited by clavulanic acid, binding was considerably enhanced and was specific as is the binding of penicillin to membranes of susceptible staphylococci (Suginaka et al., 1972; Bruns and Keppeler, 1980). Membranes from uninduced cells did not bind ${ }^{14} \mathrm{C}$-penicillin $\mathrm{G}$ specifically, but, after induction, the amount of membrane-bound $\beta$ lactamase increased about tenfold thus raising its potential protective capacity.

If intracellular $\beta$ lactamase acts at least as efficiently as excreted $\beta$ lactamase does, its influence on penicillin resistance can be calculated approximately from the results obtained with the in-vitro model described above: the amount of induced membrane-bound enzyme produced by the strains studied (table IV) should mediate resistance to concentrations of penicillin $\mathrm{G}$ of $200-800 \mathrm{mg} / \mathrm{L}$.

It has been reported (Haller, 1984) that intracellular $\beta$ lactamase could not protect staphylococci from higher concentrations of mezlocillin because resistant strains became susceptible to this penicillin when extracellular $\beta$ lactamase was washed off. However, in these experiments it is not clear how much $\beta$ lactamase was being produced in the presence of mezlocillin nor how the enzyme was distributed intra- and extracellularly. Furthermore, the method used to remove extracellular $\beta$ lactamase required simultaneous treatment of the growing cells with a constant flow of mezlocillin, continuously substituting active for degraded antibiotic for a period of at least $16 \mathrm{~h}$. Under these conditions a realistic picture of the protective power of the 
intracellular enzyme cannot be obtained because its hydrolysing capacity will be underestimated.

From the results of the present study, it can be concluded, however, that in staphylococci $\beta$ lactamase constitutes a double barrier analogous to that found in gram-negative bacteria; the outer layer, formed by extracellular $\beta$ lactamase, normally inactivates most of the penicillin before it can

\section{REFERENCES}

Batchelor F R, Cameron-Wood J, Chain E B, Rolinson G N 1963 Studies on penicillinase produced by a strain of Staphylococcus aureus. Proceedings of the Royal Society $B$ 158: $311-328$.

Bruns W, Keppeler H 1980 Mechanism of intrinsic penicillinresistance in Staphylococcus aureus. Binding of penicillin G to the cytoplasmic membrane of resistant staphylococci. Arzneimittel-Forschung/Drug Research 30: 1469-1475.

Bush K, Sykes R B 1984 Interaction of $\beta$-lactam antibiotics with $\beta$-lactamases as a cause for resistance. In: Bryan L E (ed) Antimicrobial drug resistance. Academic Press, Orlando, FL, pp 1-31.

Coles N W, Gross R 1967 Liberation of surface-located penicillinase from Staphylococcus aureus. Biochemical Journal 102: 742-747.

Dyke K G H 1979 -Lactamases of Staphylococcus aureus. In: Hamilton-Miller J M T, Smith J T (eds) Beta-Lactamases. Academic Press, London, pp 291-310.

Ericsson H M, Sherris J C 1971 Antibiotic sensitivity testing. Report of an international collaborative study. Acta Pathologica et Microbiologica Scandinavica B Supplement 217: 65-67.

Gill V J, Manning C B, Ingalls C M 1981 Correlation of penicillin minimum inhibitory concentrations and penicillin zone edge appearance with staphylococcal beta-lactamase production. Journal of Clinical Microbiology 14: 437440.

Haller I 1984 Importance of extracellular and cell-bound $\beta$ - penetrate the cells, while membrane-bound $\beta$ lactamase acts in reserve, protecting the bacterial cells when the extracellular defence, for whatever reasons, is insufficient.

We thank D. Barthold and R. Baucks for skilful technical assistance.

lactamase in mediating resistance of Staphylococcus aureus to mezlocillin. Antimicrobial Agents and Chemotherapy 25 : 125-127.

Kim T K, Chipley J R 1974 Effect of salts on penicillinase release by Staphylococcus aureus. Microbios 10A Suppl 41 : $55-63$.

Nielsen J B K, Lampen J O 1982 Membrane-bound penicillinases in gram-positive bacteria. Journal of Biological Chemistry 257: 4490-4495.

O'Callaghan C H, Morris A, Kirby S M, Shingler A H 1972 Novel method for detection of $\beta$-lactamases by using a chromogenic cephalosporin substrate. Antimicrobial Agents and Chemotherapy 1 : 283-288.

Ogawara H 1981 Antibiotic resistance in pathogenic and producing bacteria, with special reference to $\beta$-lactam antibiotics. Microbiological Reviews 45: 591-619.

Richmond M H $1975 \beta$-Lactamase (Staphylococcus aureus). Methods in Enzymology XLIII: 664-672.

Richmond M H, Curtis N A C 1974 The interplay of $\beta$ lactamases and intrinsic factors in the resistance of gramnegative bacteria to penicillins and cephalosporins. Annals of the New York Academy of Sciences 235: 553-568.

Rozgonyi F 1976 Genotypic stability of methicillin resistance in Staphylococcus aureus at supraoptimal temperature. Antimicrobial Agents and Chemotherapy 10 : 377-379.

Saz A K 1970 An introspective view of penicillinase. Journal of Cellular Physiology 76: 397-403.

Suginaka H, Blumberg P M, Strominger J L 1972 Multiple penicillin-binding components in Bacillus subtilis, Bacillus cereus, Staphylococcus aureus, and Escherichia coli. Journal of Biological Chemistry 247: 5279-5288. 